\title{
"The Role of Judicial Activism in the Implementation and Promotion of Constitutional Laws and Influence of Judicial Overactivism"
}

\author{
Vipin Kumar (NET, M.Phil.), \\ Research Scholar, Shri Venkateshwara University, Rajabpur, Gajraula (UP) Address- near K.G.K (P G) \\ College Dev Vihar Colony, Line Par, Moradabad, Mob- 945806777, 8194005705
}

\begin{abstract}
Judicial activism is today one of the most misused constitutional terms. India practices constitutionaldemocracy with emphasis on constitutionalism. This comes with it to high rates of political activities with misuse of political powers granted in the Constitution by the political actors. Naturally, the court is called upon to wear its active posture and interpret theConstitution as it affects the political class. However, each decision of the courts interpreting the constitution against the political class is met with cries of "judicial activism" from one side of the political spectrum or the other. The other cry seems to be that the courts are encroaching into the domain of the political class thereby violating the doctrine of political questions which is essentially a function of separation of powers. The paper sees these terms as being misused and makes an analytical exposition of the term and judicial intervention into political questions in India. It contends that courts should ensure the limits of governmental action under the principles of a constitutional democracy, even in the delicate field of internal affairs of governmental institutions. For this purpose, various constitutional provisions and judicial decisions are examined.
\end{abstract}

Key Words: Judicial activism, constitutional democracy, separation of powers, constitutional provisions,

\section{Introduction:-}

Today judicial activism has touched almost each and every aspect of life ranges from human rights issues to maintenance of public roads! Judicial activism means the power of the Supreme Court and the high court but not the sub-ordinate courts to declare the laws as unconstitutional and void. If it infringes or if the law is inconsistent with one or more provisions of the constitution. To the extent of such inconsistency while declaring a law as constitutional and void the courts do not suggest any alternative measures.

The term judicial activism despites its popularity to amongst legal experts, judges, scholars and politicians has not until recently been given an appropriate definition of what the term should mean so that it will not be subject to abuse. ${ }^{1}$ The effect of this has been a misconception about what the term is all about. ${ }^{2}$ This therefore creates series of definitions about the concept. Although definitions are usually products of individual idiosyncrasies and it's often influenced by the individual perception or world view, a combination of various definitions gives a description of the concept.

the Judicial Activism as innovative, dynamic and law making role of the Court with a forward looking attitude discarding reliance on old cases, and also mechanical, conservative and static views. It is the creative thought process through which the court displays vigour, enter- prise, initiative pulsating with the urge of creating new and refined principles of law. It means when the Court plays a positive role the court is said to be exhibiting the 'Judicial Activism'. There are different opinions about the origin of doctrine of Judicial Activism. Some scholars like Justice M.N. Roy believe that it is born in 1804 when Chief Justice Marshall, the greatest judge of English-speaking world, decided Marbury V Madison. But P.P. Vijayan differs with saying that Marbury V Madison is a case of Judicial Review and not of a Judicial Activism. However he opines that the judicial activism has a hoary past in Dr. Bonham's case in which Justice Coke derived doctrine of natural justice in the year 1610. In this context Dr. Suresh Mane observed that "As a result English Courts by its interpretation role extended the necessary protection; but truly, the movement of judicial activism got momentum on the soil ofAmerica under the shadow of first ever written Constitution." 1 The role of the judiciary in a modern legal system is immense social significance.... Law is in a constant process of flux and development, and though much of this development is due to the enactment of the legislature, the judges and the courts have an essential role to play in developing the law and adopting it to the needs of the Society. ${ }^{3}$

Paul Mahoney in offering his own definition of the concept submits that judicial activism exists where the judges modified the law from what was previously stated to be the existing law which often leads to substituting their own decisions from that of the elected representatives of the people. ${ }^{4}$ This definition would consider invalid actions or decisions of the judges given for the purpose of seeking the justice in a particular 
case or to interpret the law insuch a way as to conform to social realities thereby not permitting the correction of mistakes in the previous jurisprudence of law. ${ }^{\mathbf{5}}$

Famous Author SubhashKashyap says, "What has come to be called hyper activism of the judiciary draws its strength, Relevance and legitimacy from the inactivity, incompetence, disregard of law and constitution, criminal negligence, corruption, greed for power and money, utter indiscipline and lack of character and integrity among the leaders, ministers and administrators. As a result of this a vacuum was created in which the governmental machinery seemed to be totally helpless with the corruption in legislative and executive fields. The vacuum was filled in by the judiciary".

A contrary view has also been offered that the judicial activism becomes the most valuable instrument when the legislative machinery comes to a halt in a case. ${ }^{6}$ Thus, where legislative machinery could not apply to a given situation, judicial activism appears to be the most valuable instrument. In other words, judges should not be scared of adjudicating a particular case because the law has not been enacted by the legislature to cover the situation. This therefore justifies the application of judicial creativity in the matter.

Judicial Activism in India: The significant feature of Indian Constitution is partial separation of powers. -The doctrine of separation of powers was propounded by the French Jurist, Montesquieu. It is partly adopted tit India since the executive powers are vested in the president, Legislative powers tit the Parliament and the judicial powers in the Supreme Court and subordinate courts. The role of separation of powers in India is simple. The three organs of the Government viz. the Executive, Legislature and the Judiciary are not independently independent but inter-dependently independent. (The executive encroaches upon judicial power, while appointing the judges of Supreme Court and High Courts. Similarly the Judiciary, by its review power examines the law passed by file legislature parliament and the legislature also, intervenes in respect of impeachment of the president).

As stated earlier, the Judicial Activism tit India can he witnessed with reference to the review power of the Supreme Court and High Court under Art. 32 and 226 of the Constitution particularly in public interest litigation cases. The Supreme Court played crucial role in formulating several principles in public interest litigation cases. For instance, the principle of "absolute liability" was propounded in Oleum Gas Leak case. Public Trust Doctrine in Kamalnath Case (1998 I SCC .388) etc.

Further, the Supreme Court, gave variety of guidelines in various cases of public interest litigation. eg: Ratlam Municipality Case, Oleum Gas Leak Case, Ganga Pollution Case etc.

In India the concept originated after a public interest litigation was filed before the supreme court when the then Chief justice P N Bhagwati took an unknown case directly from the public who did not had any involvement in the case but it was just for the public welfare and also was related to public in large. Justice $\mathrm{P} \mathrm{N}$ Bhagwati has said that "One basic and fundamental question that confronts every democracy, run by a rule of law is, what is the role or function of a judge. Is it the function of a judge merely to declare law as it exists-or to make law? And this question is very important, for on it depends the scope of judicial activism. The anglo-saxon tradition persists in the assertion that a judge does not make law; he merely interprets. Law is existing and eminent; the judge merely finds it. He merely reflects what the legislature has said. This is the photographic theory of the judicial function". It is for the judge to give meaning to what the legislature has said and it is this process of interpretation which constitutes the most creative and thrilling function of a judge. In the initial years of 1950-67, the Supreme Court adopted the attitude of judicial restraint in which the court gave a strict and literal interpretation of the constitution.Judicial review in India was provided for expressly in the Constitution. Article 13, clause (1) says that all laws in force in the territory of India immediately before the commencement of the Constitution, in so far as they are inconsistent with the provisions containing the fundamental rights, shall, to the extent of such inconsistency, be void. Clause (2) of that article further says that the State shall not make any law that takes away or abridges any of the fundamental rights and any law made in contravention of the above mandate shall, to the extent of the contravention, be void. The Constitution also divides the legislative power between the Centre and the states and forbids either of them to encroach upon the power given to the other. Who is to decide whether a legislature or an executive has acted in excess of its powers or in contravention of any of the restrictions imposed by the Constitution on its power? Obviously, such function was assigned to the courts. The Constitution was criticized by some members of the Constituent Assembly for being a potential lawyers' paradise. Dr. B.R. Ambedkar defended the provisions of judicial review as being absolutely necessary and rejected the above criticism. According to him, the provisions for judicial review and particularly for the writ jurisdiction that gave quick relief against the abridgement of fundamental rights constituted the heart of the Constitution, the very soul of it. The nature and scope of judicial review was first examined by the Supreme Court in A.K. Gopalan case where it accepted the principle of judicial subordination to legislative wisdom. But on the whole it limited itself and exercised judicial restraint. The second phase unfolded with the Golaknath case which resulted in on open conflict between the judiciary and legislature. The parliament asserted its supremacy and the Supreme Court asserted its power of Judicial 
Review, which resulted in a series of constitutional amendments in which the parliament tried to limit the power of Judicial review. In the Emergency of 1975-77, the judiciary was made subservient to the legislature and executive. In Golaknath case, the Supreme Court gave an unprecedented judgment, which was clearly a case of Judicial Activism. The reason of imposing emergency was the decision of Allahabad High Court setting aside the election of Prime Minister Indira Gandhi to the LokSabha. The 42nd constitutional Amendment Act was also passed which put new limitations on the judiciary. After the emergency the 44th constitutional Act was passed which restored the judiciary's position as it had existed before the emergency. In Minerva mills case the Supreme Court declared judicial review as part of the basic structure. Since 1980's we saw the emergence of Judicial Activism as a powerful tool in Indian Polity. Thus now we find that the Supreme Court is no longer exercising judicial restraint. But in fact, it has taken up Judicial Activism so much. A court giving new meaning to a provision so as to suit the changing social or economic conditions or expanding the horizons of the right of the individual is said to be an activist court. Thus has given birth to Judicial Activism. In the words of Justice J. S. Varma "The role of the Judiciary in interpreting existing laws according to the needs of the times and filling in the gaps appears to be the true meaning of Judicial Activism. ${ }^{7}$

\section{Present scenario of Judicial activism or Judicial overactivism:-}

Of late the Indian judiciary appears to have become overactive, and is often accused of judicial overreach. This accusation was usually leveled by politicians or others outside the judicial system, until in 2008 it was leveled by Justice A.K. Mathur and the writer (as Judges of the Supreme Court) in Divisional Manager, Aravalli Golf Course v. Chander Haas. The Indian Supreme Court surely came a long way since Anwar Ali Sarkar Vs. State of West BengalAIR 1952 SC 75 and A.K. Gopalan Vs. State of Madras where the judiciary refused to indulge in making judicial policy and instead exercised judicial restraint keeping in mind the Doctrine of Separation of Powers. However, the pendulum later swung to the opposite direction. Thus, in Maneka Gandhi vs. Union of India AIR 1978 SC 593 the 7 Judge Bench of the Indian Supreme Court, while overruling the 5 Judge Bench decision in A.K. Gopalan'scase introduced the due process clause in the Indian Constitution by a judicial pronouncement. In S. P. Gupta Vs. Union of India ,AIR 1982 SC 149 it was held that:"He [the judge] has to inject flesh and blood in the dry skeleton provided by the legislature and by a process of dynamic interpretation, invest it with a meaning which will harmonize the law with the prevailing concepts and values and make it an effective, instrument for delivery of justice."

Similarly, in the case of Supreme Court Advocates on Record Vs. Union of India,1993 4 SCC 44it was held that: "It belongs to the Judiciary to ascertain the meaning of the constitutional provisions and the laws enacted by the Legislature."

This was the advent of an over active judiciary which assumed upon itself the need to adjudicate even where it was not perceived to be warranted. Although Article $\mathbf{5 0}^{(\mathbf{8})}$ of the Indian Constitution expressly provides for Separation of Powers between the different organs of the State, but time and again, the Indian Supreme Court has taken on itself the task of filling in the gaps created by the Legislature and the Executive to do 'justice'.

While doing so, the judiciary has been often criticized for overstepping its limits. In the case of VineetNarainvs. Union of India, 1998 Cri. L. J. 1208 the Supreme Court had invented a new writ called "continuing mandamus" where it wanted to monitor the investigating agencies which were guilty of inaction to proceed against persons holding high offices in the executive who had committed offences. Furthermore, the Court created by its judicial order a body called the Central Vigilance Commission, which was not contemplated by the statute (the Delhi Special Police Establishment Act, 1946), for supervising the functioning of a statutory body, the Central Bureau of Investigation. The Court also laid down a number of guidelines for the appointments of chiefs of investigating agencies like Central Bureau of Investigation, Central Vigilance Commission and the Enforcement Directorate; apart from the Chiefs of the State Police. These guidelines, apart from being in relation to appointment, were also with regard to their status, transfer and tenure, etc. The question arises whether this was legitimate exercise of judicial power.In the case of Indian Council for EnviroLegal Action Vs. Union of India, (1996) 5 SCC 281 the Court passed various orders especially directed towards the States requiring them to submit management plans to control pollution to both, the Central Government as well as the Court. Here, the Court held that it was only discharging its judicial functions in ensuring that it remedies the errors of the executive.

In the case of M. C. Mehta vs. Union of India, (2001) 3 SCC 763 where a writ was filed with regard to the vehicular pollution in Delhi, the Supreme Court had passed directions for the phasing out of diesel buses and for the conversion to CNG. When these directions were not complied with due to shortage in supply of $\mathrm{CNG}$, the Court held that orders and directions of the Court could not be nullified or modified by State or Central governments. This was a case where, despite several directions being given by the Supreme Court, the government did not act speedily in responding to the Order. 
The Court has prescribed norms regarding the running of the prisons and mental intuitions, ${ }^{9}$ instructed the Government to implement labor laws at construction sites, ${ }^{10}$ recognised admissions in medical colleges throughout India laying down examination schedules, ${ }^{11}$ prescribing hawking zones in metropolitan cities, ${ }^{12}$ laid down the guidelines for the retail outlets for essential commodities such as LPG, ${ }^{13}$ resolving disputes between public undertakings of Central Government, ${ }^{14}$ directed the authorities like C.B.I to conduct and complete investigation expeditiously in cases of national importance,${ }^{15}$ directed the noxious factories to restart on the technical reports on safety measures ${ }^{16}$ prescribed the poverty limits for the low income urban housing ${ }^{17}$ or set up an expert panel headed by a retired Supreme Court to study the vehicular pollution level ${ }^{18}$ etc. In these decisions the court did legislate, but in the process was criticized for having infringed upon the executive domain.

With due respect to these and other decisions it has to be said that many judges often forget that the judiciary cannot solve all problems in the country. Suppose the Court passes an order that from tomorrow poverty in India, or unemployment, or malnutrition etc. are abolished. Will these orders mean anything? Can they really be implemented? India is a poor country with limited financial resources. Moreover, many such orders e.g. for interlinking rivers vide In re Networking of Rivers (2012) 4 S.C.C. 51 raise great technical and administrative problems, and are really in the domain of the legislature or executive.

The most recent case on judicial activism was the case of ArunaRamchandraShanbaugVs. Union of India and Others. JT 2011 (3) SC 300.ArunaShanbaug, a nurse in 1973, while working at a Hospital at Mumbai, was sexually assaulted and has been in a permanent vegetative state since the assault. In 2011, after she had been in this status for 37 years, the Supreme Court of India heard the petition to the plea for euthanasia filed by a social activist claiming to be Aruna's friend. The Court turned down the petition, but in its landmark judgment (authored by the writer) it allowed passive euthanasia i.e. withdrawal of life support to a person in permanently vegetative state, subject to approval by the High Court.

\section{Trends in Judicial Restraint:-}

Rising judicial activism was hindering governance in the country and impacting growth in Asia's third largest economy, finance minister P Chidambaram said.

"Nowhere in the world would we see ideal balance between legislature and judiciary. But in India, we have seen intensifying judicial activism, which had impacted the balance of governance," Chidambaram said at The Economic Times Awards for Corporate Excellence.

"The balance in India has swung away from the executive and the parliament," he said. "The judiciary has taken an upper hand. Unless the executive has a final say, we cannot have sustained high growth rate. Countries like China, Brazil and Mexico, with a stronger executive authority, have exhibited better growth trajectory," he argued.

"Judicial institutions cannot take over governance. We must rediscover the balance between our institutions and we have to reassert the balance between reforms, development and institutions," Chidambaram said.

Sounding a note of caution on judicial activism, The President of India Mr. Pranab Mukherjee said judicial pronouncements must respect the boundaries that separate the legislature, executive and judiciary. Making his first visit outside the national capital after assuming the office of President on July 25, Mukherjee also said that everything must be done to protect the independence of judiciary from any form of encroachment. Addressing the valedictory function of the 150th anniversary celebrations of the Madras High Court, he urged judiciary to keep reinventing itself through a process of introspection and self-correction at the same time. In his address, Mukherjee touched upon various issues that dominate legal discourse including judicial accountability and the appointment of judges. The President referred to judicial activism and said the judges through innovation and activism have contributed enormously to expanding the frontiers of justice and providing access to the poorest of the poor. ${ }^{19}$

The Supreme Court in an order has said that the judiciary must refrain from encroaching on legislative and executive domain otherwise it will boomerang in the form of political class stepping to clip their wings. A bench comprising Justice AK Mathur and Justice MarkandeyKatju said, "If the judiciary does not exercise restraint and over-stretches its limit there is bound to be reaction from politicians and others. The politicians will then step in and curtail the powers or even independence of the judiciary. The judiciary should, therefore, confine itself to its proper sphere, realizing that in a democracy many matters and controversies are best resolved in a non-judicial setting." The court said that justification often given for judicial encroachment into the domain of the executive or legislature is that the other two organs are not doing their jobs properly. Even assuming this is so, the same allegation can then be made against the judiciary too because there are cases pending in courts for half-a-century, bench said. If they are not discharging their assigned duties, the remedy is not judicial interference as it will violate delicate balance of power enshrined in the constitution, remarked the court. $^{20}$ 
There are many examples where judiciary had encroached upon the turf which was unwarranted. The Jagdambika Pal caseof 1998 involving UP legislative assembly and the Jharkhand assembly case of 2005 are the two glaring examples of deviations from the clearly provided constitutional scheme of separation of powers, said bench.

There is broad (though not absolute) separation of powers in the Indian Constitution vide Divisional Manager, Aravali Golf Course vs. Chander Haas, 2008. The Constitution of India did not provide for the judiciary to be a super legislature or a substitute for the failure of the other two organs. Thus, the need arises for the judiciary to lay down its own limitations.

Some people say that the judiciary can enter into the domain of the executive or legislature because these organs are not functioning properly. But then it can also be said that the judiciary, too, is not functioning properly, there is great delay in deciding cases, corruption in a section of the judiciary, etc. Should then the legislature or executive take over the judiciary's function?

One of the examples of judicial restraint is the case of State of Rajasthan Vs. Union of India,AIR 1977 SC 1361, in which the court rejected the petition on the ground that it involved a political question and therefore the court would not go into the matter. In S.R. Bommai Vs. Union of India,(1994) 3 SCC 1, the judges said that there are certain situations where the political element dominates and no judicial review is possible. The exercise of power under Art.356 was a political question and therefore the judiciary should not interfere. Ahmadi J. said that it was difficult to evolve judicially manageable norms to scrutinize the political decisions and if the courts do it then it would be entering the political thicket and questioning the political wisdom, which the court must avoid. ${ }^{21}$

In Almitra H. Patel Vs. Union of India, (2000) 2 SCC 679, where the issue was whether directions should be issued to the Municipal Corporation regarding how to make Delhi clean, the Court held that it was not for the Supreme Court to direct them as to how to carry out their most basic functions and resolve their difficulties, and that the Court could only direct the authorities to carry out their duties in accordance with what has been assigned to them by law. Also, in Union of India Vs. Kishan K. Sharma, (2004) 5 SCC 518, when the High Court issued a Mandamus to the Government to pay a particular scale to its officers, the Supreme Court laying down the boundaries of judicial activism in general held that such Mandamus would not be permissible as fixation of salaries was an administrative decision. Similarly, creation of a post is an administrative or legislative functions, and cannot be done by the court vide Divisional Manager, Aravali Golf Course (supra)

\section{Conclusion:-}

However, the governance cannot be replaced by the judicial institutions. There is a need to discover a balance between judicial and executive institutions. We need to reassert the balance between reforms, development and institutions. Judicial activism should not be used to lead to the Constitutional principles of separation of power getting eroded. Our Hon'ble Judges should not cross their limits in the name of judicial activism and not to try to take over the functions of other organs of administration. Judicial pronouncements must respect the boundaries that separate the Legislature, Executive and Judiciary. TheJudicial Activism has touched almost every aspect of life in the present times. Be it the case of bonded labor, illegal detentions, torture and maltreatment of women, the implementation of various provisions of the constitution, environmental problems, health, sports etc. the courts took cognizance of each case and laid down various judgments to protect the basic human rights of each and every member of society. However, the politicians and some constitutional experts criticize judicial activism and on the other hand the lawyers and public has welcomed it with warm hands. It is important to note that judicial Activism has so many merits but it has certain demerits. Here it is important to note that we cannot lead the government on judicial basis only. Frequent confrontation between the Legislature, Executive and the judiciary will also damage our well established democratic system of governance. The members of every institutionsworn to uphold the constitution, which alone is supreme. Both sides will maintain and respect the line of demarcation of power under the constitution and will not allow a conflict to develop between them.

By evolving the doctrine of Basic Structure of the Constitution, the Hon'ble Supreme Court of India has limited the power of Parliament to amend the constitution. The court's increased activism has been good and contributed a lot for India's democracy. The expensive, technical justice now becomes inexpensive and nontechnical through the growth of Public Interest Litigations. The important question today is not whether the Supreme Court could activate its judicial role, but to what extent the concepts of Judicial Activism and creativity are exercised. A balance between the powers of Judiciary, Legislature and executive is necessary to carry the nation on the true path of democracy. 


\section{References:-}

[1]. See for instance some of the work that are on judicial activism without really defining the term. Chad M. Old father, "Defining Judicial Inactivism: Models of Adjudication and the Duty to Decide" (2005) 94, Geo. L.J. 121, 122

[2]. Keenan D. Kmiec, "The Origin and Current Meanings of "Judicial Activism," (2004) 92, Cal. L. Rev., 1441, 1442;See also Bradley C. Canon, "A Framework for the Analysis of Judicial Activism" in Stephen C. Halpem\& Charles M. Lamb eds., Supreme Court Activism And Restraint 1982, 385, 386 (describing prevalent activism debates as "little more than a babel of loosely connected discussion")

[3]. Cardozo Benjamin N, The Nature of the Judicial Process, Universal Law Publishing Co.Pvt.Ltd., Delhi, (2004)

[4]. Paul Mahoney, "Judicial Activism and Judicial Self-Restraint in the European Court of Human Rights: Two Sides of the Same Coin” (1990) 11, Hum. Rts. L.J. 57, 58.

[5]. DragoljubPopovic, "Prevailing Judicial Activism over Self Restraint in the Jurisprudence of the European Court of Human Rights" ( 2009) vol. 42, Creighton Law Review, 361 at 363.

[6]. Thijmen Koopmans, "The Roots of Judicial Activism in Protecting Human Rights: The European Dimension, Studies In Honor Of Gérard J. Wiarda 326 (F Matscher\& H. Petzold Eds., 1988).

[7]. JUDICIAL ACTIVISM IN INDIA- An Overview (By Arjun.M, Administrative Assistant, Centre for Public Policy Research)

[8]. Article 50: The State shall take steps to separate the judiciary from the executive in the public services of the State.

[9]. SheelaBarsevs. State of Maharashtra, (1983) 2 SCC 96

[10]. Labors on Sala Hydro Electricity Project Vs. State of J \& K, (1984) 3 SCC 538

[11]. Pradeep Kumar Jain Vs. State of .P., AIR 1984 SC 1420

[12]. Bombay Hawkers Union Vs. B.M.C., (1985) 3 SCC 528

[13]. Center for PIL Vs. Union of India, 1995 Sppl. (3) SCC 382

[14]. ONGC Vs. Collector of Central Excise, 1995 Sppl. (3) SCC 541 (This decision has since been reversed)

[15]. Supra footnote 51

[16]. M. C. Mehta v. Union of India, (1986) 2 SCC 176

[17]. Shantisar Builders Vs. L. Narayan, (1990) 1 SCC 520

[18]. M. C. Mehta v. Union of India, (1991) 2 SCC 353

[19]. Pranab Mukherjee's note of caution on judicial activism PTI Sep 8, 2012, 07.33PM IST

[20]. SC asks courts to curb judicial activism Sanjay K Singh, TNN Dec 11, 2007, 12.49am IST

[21]. "Judicial Activism v. Judicial Self-Restraint" athttp://legalsutra.org/933/judicial-activism-v-judicial-self-restraint/ as last on 10 July, 2011 